\title{
Perceptual Image of Non-Fiction Text Author (Exemplified by L. Niemirowski's Letters)
}

\author{
Alexander V. Shunkov and Natalia V. Deeva* \\ Kemerovo State Institute of Culture \\ 17 Voroshilova Str., Kemerovo, 650056, Russia
}

Received 10.01.2017, received in revised form 17.08.2017, accepted 25.08.2017

\begin{abstract}
The article deals with the analysis of the letters by the Polish painter L. Niemirowski. These letters were written during his exile in Eastern Siberia (1844-1845) and addressed to his compatriot Yu. Sabin'sky. Niemirowski's epistolary writings are a valuable historical and literary material that allows presenting the spiritual world of the exiled Poles of the early 19th century. Evaluation plan, the plan for selecting language means, the plan of factual information and the plan of psychology allow recreating the image of the letters' author in detail. Despite multi-addressee Niemirowski's letters are deeply personal. Their author appears to the reader as a man of exceptional intelligence, critical thinking and creative vision of reality, who is endowed with a delicate soul and a strong character. The motives of melancholy, loneliness and memory became the leitmotif of Niemirowski's letters.
\end{abstract}

Keywords: epistolary genre, the image of the author, epistolary fund of Polish political exiles the early 19 th century.

DOI: $10.17516 / 1997-1370-0157$.

Research area: philology.

\section{Introduction}

The issue of the image of the author is one of the most studied in linguistics and literary studies. The concept of "the image of the author" was introduced into scientific practice in domestic linguistics in connection with the analysis of fictional texts (Vinogradov, 1980). Of course, the analysis of any non-fiction text is also able to reveal the individual characteristics of its author. Analyzing letters (their topics, compositions and language peculiarities) it is possible to judge about the level of general culture, outlook, interests and the inner state of the person who wrote them.
Leopold Niemirowski is a unique personality and information about him has been preserved in a few specific scientific works of Polish researchers (Shostakovich, 2010). However, even this small amount of sources that contains biographical information about an activist of the Polish liberation movement and a political exile, makes it possible to draw conclusions about L. Niemirowski as of a talented painter whose paintings are not only of artistic value but also of interest to historians and ethnographers.

Being in exile (1839-1857) that was later replaced by penal settlement in the suburbs of Irkutsk determined L. Niemirowski's interest

(C) Siberian Federal University. All rights reserved

* Corresponding author E-mail address: alexandr_shunkov@mail.ru; deeva24@1ist.ru 
to the habits, customs and the way of life of the indigenous population of Eastern Siberia and found their artistic embodiment in his artworks. It is known that "after returning from exile, Niemirowski exhibited his works at exhibitions in Paris (1867) and in the Society for the Support of Fine Arts in Warsaw (1870)". Drawings and paintings of the painter enjoyed great attention there and it "affected their sale - the price for drawings reached 200 rubles" (Chaikovski, 2010: 6).

In 1844 Niemirowski, as a draftsman, was included in the expedition of the Russian Geographical Society, which was sent to the Sea of Okhotsk, to Kamchatka, to study the territories inhabited by the Koryaks, Yakuts and Chukchi. The results of the Polish exiled painter's participation in the expedition were the works drawn in pencil and watercolor, even now being of great artistic value. Several works were published in 1856 by I.D. Bulychov, the head of the senatorial verification of Kamchatka, in Petersburg without the name of the Polish painter (Bulychov, 1856).

\section{Statement of the problem}

L. Niemirowski's heritage is represented not only by his paintings, but also by epistolary works, where one of the addressees is Yu. Sabin'ski, a Polish exile as well, the author of the well-known work "The Siberian Diary. 1838-1857". Niemirowski's letters along with Sabin'ski's writings (a diary that he himself called "Nineteen Years, Torn from My Life, or the Diary of My Captivity and Exile from 1838 to 1857 Inclusive"), Sh. Tokazhevsky (Shunkov, 2012) and others Polish exiles are a rich material for linguocultural and literary studies.

The material for the analysis in this work was personal letters of L. Niemirowski to Yu. Sabin'sky, in the period from 1844 to 1845. The specific character of the research material requires clarification of the term "the image of the author", which in this paper is understood as "information about the general characteristics of the sender implicitly or explicitly reflected in the text" (Baklanova, 2014: 7). The perceptual image of the author is an image of the author in the form it is perceived by the reader. The content of letters, the ways of expressing evaluation, transmission of factual information and the selection of linguistic means in them make it possible to give full representation of the image of the person who wrote them.

\section{Discussion}

L. Niemirowski's letters to Yu. Sabin'sky are a reflection of his fears, yearn for close people and hard-lived loneliness while traveling to Kamchatka. Almost in each letter the author writes about his isolation from a circle of people close to him, the motif of melancholy and suffering became the key motif in the texts: Jak tęskno! jak tęskno za wami! (Ochock, 5 sierpnia 1844 r.); ...Chociaż jeszcze blizko trzy miesiace będę musiat tęsknić za wami (Jakuck, 18 kwietnia 1845 r.); Ale nie mniej przewidziana tęsknota po was spotkata mnie w pierwszych krokach, $i$ dotad nieodstepna jest moja towarzyszka (Jakuck, 30 maja 1844 r.); Smutno, tęskno samemu śród cudzych ludzi, serc $i$ wyobrażeń (Jakuck, 15 maja 1845 r.).

Mentioning his longing for Irkutsk, the place of serving the exile in one of the letters also indicates of the fact how painfully L. Niemirowski experienced his departure: Żal mi teraz Irkucka $i$ jego okolic, tak, jakbym tam własna zostawit rodzine (Jakuck, 30 maja 1844 r.). For the exiled painter Irkutsk became something like home, since like-minded persons and his friends stayed there.

The moment of return and meeting with close people is called a sweet moment in the letters: Dlatego czekam niecierpliwie stodkiej dla mnie 
chwili powrotu... (Jakuck, 15 maja 1845 r.). In the last letter, before his return to Irkutsk, the painter writes that he was going back not with a heart full of sadness, but with benevolent feelings; the melancholy is replaced by the anticipation of the joy of the meeting: Wracam więc do was z sercem petnim nie żalu i obojętności, ale szczerych, przychylnych uczuć (Jakuck, 18 maja 1845 r).

For L. Niemirowski the letters to the close people and their replies remained the only connecting bridge with the people that he loved and valued so much, the only source to fight loneliness. That is why in each letter he asks not to forget him and to write back to him: Spominajcie mnię czasom: a każde to spomnienie odbije sie w sercu moim (Kaczuga nad Leną, 14 maja 1844 r.); Na miłość Boga, pisujcie! (Ochock, 5 sierpnia 1844 r.); Proś wszystkich, żeby pisali do mnie... (Ochock, 1 września 1844 r.).

The author also formulates the purpose of his messages, the letters are the only thing that gave him comfort, gave an opportunity, even only mentally, to be close to those who were really dear to him: Nie umieszczam żadnych opisów z podróży: bo pisze te listy jedynie tylko seca potrzeby zaspokajania (Jakuck, 15 maja 1845 r.). The painter's words from an earlier letter also bear evidence of how important the correspondence with the close people was for him: Jezeli nie zostane tu za powrotem waszych listów: to gotów będę pozostać gdzie śród Tunguzów (Ochock, 5 sierpnia 1844 r.).

In each of his letters L. Niemirowski sends greetings to the close people and acquaintances. For him, obviously, it was not just a tribute to etiquette, but a desire to be closer, to remain relative and a friend in the thoughts and hearts of others: Pań naszych ręczki ucatujcie ode mnie. Nazawzse wdzięczność zachowam za ich uczucia sióstr przy odjezdzie mnie okazane (Kaczuga nad Leną, 14 maja 1844 r.); Uściskaj wszystkich braci ode mnie. Pani Antonilli i pani Ludwiki ręczki ucałuj (Jakuck, 30 maja 1844 r.); Wktadam na ciebie mity obowiazek uściskania po bratersku wszystkich kolegów: a paniom naszym objawienia przychylniejszych pozdrowień (Jakuck, 3 lipca 1844 r.). As well as he, with all his thoughts and feelings, was always among those close to him: Nie wiem, czy tóż serca wasze czuja, kiedy, jak ja myśla ciagle bładze pomiędzy wami? (Ochock, 5 sierpnia 1844 r.); Kiedy wzrok mój ślizgat się po blyszczacych falach oceanu, lub po szczytach śnieżnych gór Stanowego tancucha; albo też przenikat ciemne gestwiny odwiecznych lasów: wszędzie ja sercem i myśla bytem z wami (Jakuck, 18 maja 1845 r.). Thus, memory became another key motif of the painter's letters.

Undoubtedly, any letter has a specific addressee (a person or a group of persons), and as the author himself indicated, his letters were addressed not only to Yu. Sabin'sky, these were messages to all his friends and acquaintances: Listy moje, jak ten, do was wszystkich, kochani bracia, należa. Czytajcie je, jeżeli pamięć o mnie jest wam mita, jak dla mnie moje o was spomnienia (Kaczuga nad Leną, 14 maja 1844 r.). Cordial attitude of the painter to the addressee (addressees) is conveyed by the adjectives "amiable", "dear", "beloved" and "kind": kochany Julianie, kochani bracia, poczciwy mój Julianie. The choice of adjectives for address in L. Niemirowski's letters does not simply follow epistolary etiquette, but it is a way of conveying his personal attitude and feelings that overwhelmed him.

In his letters L. Niemirowski remains a painter, but he appears as a word-painter in them. His descriptions of nature (albeit a few) in letters represent depictions splendid in language accuracy and expressiveness: Wyobraż sobie od Kaczugi aż do Ochocka jeden obszerny las, puszczę, śród której wije się jak wstązka dtuga ale jedna ścieżka z poczatku korytem Leny śród skat różnej formacji; a potem, od Jakucka ladem, śród wzgórz i gór ogromnych skalistych, przez rzeki, 
jeziora, skaty, szczyty gór, lody i trzęsawisko... [...] Skaty $i$ woda. Jest wprawdzie trochę i ziemi: ale ta tak mała warstwa kryje skalista posadę: że na niej zaledwie tutejsze drzewa, mchy, leśne trawy i kwiaty po wierzchu gatęzić moga swoje korzenie (Judomski Krest, 3 lipca 1844 r.). In general, the language of the painter's letters is distinguished by expressiveness, active use of metaphors, epithets and other means of figurative language: A pamiętaj, pisz jak najczęściej; i nie zapomnij: że nowiny od was najlepsza będa dla mnie jatmużna; dla mnie tak ubogiego $w$ wasze towarzystwo (Jakuck, 30 maja 1844 r.); Pamiętaj, że ja teraz jak ostryga zamknięty tu sobie żyję [...] (Ochock, 5 sierpnia 1844 r.).

The inner world of man can be judged by the assessments that he gives to the people and events that surround him. L. Niemirowski writes with great respect not only about his friends: Mocno mię ucieszyła wiadomość: iż się zbliżacie z dobrym moim Walerym, którego ja pięty nie wart jestem (Judomski Krest, 3 lipca 1844 r.), but also about the people who he had to travel with. The author of the letters expresses high opinion of their upbringing and education: $O$ najważnejszem nic wam jeszcze nie spomniatem. Próżne byty moje obawy. W towarzyszach moich najmilszych ludzi znalazłem. Dobre wychowanie i oświata pośredniczyć będa zawsze pomiędzy nami (Kaczuga, 14 maja 1844 r.); Powiem ci tylko: iż mocno kontent jestem z towarzystwa kolegów moich, z którymi kto inny, zdolniejszy do towarzystwa niż ja, najprzyjemniej mógłby czas przepędzić (Jakuck, 30 maja 1844 r.); Co do moich towarzyszów podróży, mogę wiele powiedzieć na ich pochwale. Coraz więcej zbliżamy się z sobao ile tylko to być może. W obejściu się ich zawsze [...] grzeczność $i$ uprzejmość. Słowem: z tej strony nic mi nie pozostaje do życzenia (Jakuck, 3 lipca 1844 r.). However, it is noteworthy that mentioning his travel companions as a whole, the author of the letters does not mention their names or surnames, which may indicate of the distance that existed between the Polish exiled painter and other travelers.

Despite the difficulties of travel and constant yearn for the close people, the author of the letters does not complain about his fate, on the contrary, he finds positive moments even on such a difficult trip: Dziś ocean nowe nastręcza nam ciekawości. To jedno warto trudów podróży (Ochock, 5 sierpnia 1844 r.); Zdrów jestem. Nie czuję bynajmniej trudów podróży. Przejazdka tu z Jakucka konno byta dla mnie rozrywka: $i$ dalszych trudów ochocza wygladam (Ochock, 5 sierpnia 1844 r.), that can evidence of strong character and the ability to see good in any situation.

A man of outstanding mind, L. Niemirowski discoved a lot for himself during the journey: Teraz powiedzieć moge, że widziatem nature w jej pierwobytnym stanie. Pustynia bez końca, gdzie czlowiek jest zjawiskiem, jakby tylko przyszedt na ziemie. Wiele miejsc prawdziwie piskowych, a mnóstwo rzadkich i zajmujacych widzieliśmy po drodze. Wiele nowych przedmiotów, zdarzeń, zjawisk $i$ wrażeń spotkaliśmy śród tych dzikich skat i lasów (Ochock, 5 sierpnia 1844 r.); Robiłem tudwie wycieczki, wgłą gór tańcucha Morekanu. Szukałem i znalazłem dość morekanitów: rodzaj to granatów, dalekich wprawdzie co do pozoru, od granatu szlachetnego: ale zawsze zalecaja się twardościa, oraz pięknościa wewnętrzych deseni i potysku. Drugie sa przezroczyste, ale zadymnione bez wyraźnego koloru (Ochock, 1 września 1844 r.). At the same time, he did not only describe what he saw, but also critically assessed what he was observing around: Bez watpienia: że oryginalniejszej podróży niktby nawet wymyślić nie mógt. Niewielkim bytoby grzechem nazwać tę część świata pustynia zupetnie jeszcze niezwidzona. Zaledwie kilku myślacych ludzi te trudna przebiegło drogę. Corocznie wprawdzie przejeżḋaja tędy kupcy 
i Jakuty. Ale oni myśle wszystkie zawsze ograniczają na swej kieszeni, ani wrażeń podróży udzielić, ani korzyści umiejętnościom przynieść nie sq $w$ stanie (Judomski Krest, 3 lipca 1844 r.). The people who the painter met (it is reffered to the indigenous population of Kamchatka) are compared to animals and, in the opinion of the letters' author, differ little from them: Zwierzat napotkasz tu mnóstwo i różnych rodzajów. Ale ludzie, mało od pierwszych różnia się [...] (Judomski Krest, 3 lipca 1844 r.).

L. Niemirowski's letters also contain humorous remarks and delicate irony: Sam sie przekonatem, jak ruch i myśl swobodniejsza, korzystnie wptywaja na biedna nasza machine (Jakuck, 18 maja 1845 r.) - it is referred to the human body; Jeździć będziemy jeszcze na jeleniach, psach, ledwie nie na kotach, wszystkimi sposobami jakie tylko sa na świecie (Ochock, 5 sierpnia 1844 r.).

L. Niemirowski's letters to Yu. Sabin'sky are expressions of what was happening in the painter's soul on paper, abstract philosophical reflections and reflections on social topics occupy an insignificant part in them. In one of his letters, for example, he reflects on human happiness and he sees the hearts of other people as its source: Miałem wiele czasu do swobodnego myślenia $w$ tej podróży. [...] A rozpamiętywajac często o tym, co zwykle pomyslnościa nazywaja na ziemi, kończyłem zawsze wnioskiem: iżjedynym źródtem szczęścia jest wlasne innych ludzi serca (Jakuck,
18 maja 1845 r.). In another letter he mentions (not without a critical remark) Yu. Sabin'sky's educational activity in Irkutsk: Co wszakże niech to będzie powiedziano bez obrażenia ciebie - nie wielka mi robi nadzieje, aby przez to daleko jaśniej było w Irkucku za moim powrotem. Bo tam wiele głów jak rewerbery: które odbija, a nie potykaja promienie. Przyznaje, że to ani twoja wina, ani ojca Adama. Bo wiem, że ty nie żałujesz ani oliwy, ani trudów...Ale też masz roboty potężnie! (Jakuck, 18 kwietnia 1845 r.).

\section{Conclusion}

In personal letters, the image of the author (the presence of the author) is manifested in its maximum, since this genre is focused on the reflection of the subjective perception of events and conveying the feelings of the author. In the letters to Yu. Sabin'sky L. Niemirowski appears as a man endowed with the powers of observation, an inquiring mind, an ardent heart, able to appreciate friendship, care and nothing else, but a good attitude. The author of the letters is distinguished by a high level of general and linguistic culture. L. Niemirowski expressed his lively interest in people, their traditions and unique nature of north-eastern part of Russia in the drawings brought from the travel; but another theme was predominant in the letters to his friend: the world of personal feelings, sincere experiences and the hopes of the human "I" of the painter.

\section{References}

Baklanova, I.I. (2014). Obraz avtora i obraz adresata nekhudozhestvennogo teksta [The Image of the Author and the Image of the Recipient of the Non-Fiction Text]. Moskow, Gosudarstvennyi institut russkogo iazyka im. A.S. Pushkina, 272 p.

Bulychov, I. (1856). Puteshestvie po Vostochnoi Sibiri. Iakutskaia oblast'. Okhotskii krai [Travel to Eastern Siberia. Yakut Region. Okhotsk Region]. Vol. 1. St. Petersburg, Tipografiia Imperatorskoi Akademii nauk, $298 \mathrm{p}$. 
Chaikovski, K. (2010). Leopol'd Nemirovskii. V 200-iu godovshchinu so dnia rozhdeniia [Leopold Niemirowski. The $200^{\text {th }}$ Anniversary of Birth], In Journey of Leopold Niemirowski through Siberia: Drawings, Lithographs, Watercolors. Irkutsk, Artizdat, 5-6.

Shostakovich, B. (2010). Leopol'd Nemirovskii - pol'skii khudozhnik, politicheskii ssyl'nyi v Vostochnuiu Sibir' epokhi dekabrizma (k 200-letiiu so dnia rozhdeniia) [Leopold Niemirowski Polish Artist, Political Exile to Eastern Siberia of the Decembrist Epoch (the 200 $0^{\text {th }}$ Anniversary)], In Journey of Leopold Niemirowski through Siberia: Drawings, Lithographs, Watercolors. Irkutsk, Artizdat, 7-14.

Shunkov, A.V. (2012). Sibir' v pol'skoi belletristike XIX veka (Shimon Tokarzhevskii i ego povesti o sibirskoi katorge) [Siberia in the Polish Fiction of the $19^{\text {th }}$ Century (Shimon Tokarzhevsky and His Stories about the Siberian Servitude)], In Nauchnoe obozrenie: gumanitarnye issledovaniia [Scientific Review: Humanities Research]. 1, 138-144.

Vinogradov, V.V. (1980). O iazyke khudozhestvennoi prozy [About the Language of Fiction Prose]. Moskow, Nauka, 360 p.

\title{
Перцептивный образ автора нехудожественного текста (на материале писем Л. Немировского)
}

\author{
А.В. Шунков, Н.В. Деева \\ Кемеровский государственный институт культуры \\ Россия, 650056, Кемерово, ул. Ворошилова, 17
}

Сочинения Л. Немировского органично вписаны в традицию польской литературы, осмыслливающей исторический сюжет сибирской каторги. В статье анализируются письма польского художника Л. Немировского, написанные им во время путешествия на Камчатку (1844-1845 г2.) и адресованные его соотечественнику, политическому ссыльному, Ю. Сабиньскому. В письмах Л. Немировского образ автора идентичен личности художника, в них большое место отводится описанию переполнявших польского ссыльного чувств. Мотивы тоски, памяти, тяжело переживаемого одиночества становятся в письмах ключевыми. Язык и стиль писем Л. Немировского позволяют охарактеризовать их автора не только как человека образованного, но и творческого. Наблюдательность, критичность ума, благородство, душевная чуткость, вера в собственные силь - вот, что отличает образ автора, возникающий при прочтении писем.

Ключевые слова: эпистолярный жанр, образ автора, эпистолярный фонд польских политических ссыльных первой половины ХІХ в.

Научная специальность: 10.00 .00 - филологические науки. 